\title{
IL21 wt Allele
}

National Cancer Institute

\section{Source}

National Cancer Institute. IL21 wt Allele. NCI Thesaurus. Code C104345.

Human IL21 wild-type allele is located within 4q26-q27 and is approximately $8 \mathrm{~kb}$ in length. This allele, which encodes interleukin-21 protein, is involved in both immunity and signaling. 